RESEARCH ArTiCLE

Published June 7, 2021

\title{
ANTIBODY ReSPONSES TO SARS-CoV-2 mRNA Vaccines Are Detectable in Saliva
}

\section{AUTHORS}

Thomas J. Ketas ${ }^{1,+}$, Devidas Chaturbhuj ${ }^{1,+}$, Victor M Cruz Portillo ${ }^{1}$, Erik Francomano ${ }^{1}$, Encouse Golden $^{2}$, Sharanya Chandrasekhar ${ }^{2}$, Gargi Debnath ${ }^{1}$, Randy Díaz-Tapia ${ }^{1}$, Anila Yasmeen ${ }^{1}$, Kyle D. Kramer ${ }^{1}$, Tarek Munawar ${ }^{1}$, Wilhelm Leconet ${ }^{3}$, Zhen Zhao ${ }^{4}$, Philip J.M. Brouwer ${ }^{5}$, Melissa M. Cushing $^{4}$, Rogier W. Sanders ${ }^{1,5}$, Albert Cupo ${ }^{1}$, Per Johan Klasse ${ }^{1}$, Silvia C. Formenti ${ }^{6}$, John P. Moore $^{1^{*}}$

\section{AFFILIATED INSTITUTIONS}

${ }^{1}$ Department of Microbiology and Immunology, Weill Cornell Medicine, New York, New York ${ }^{2}$ Department of Radiation Oncology, Weill Cornell Medicine, New York, New York ${ }^{3}$ Department of Urology, Weill Cornell Medicine, New York, New York

${ }^{4}$ Department of Pathology and Laboratory Medicine, Weill Cornell Medicine, New York, New York

${ }^{5}$ Department of Medical Microbiology and Infection Prevention, Amsterdam University Medical Centers, University of Amsterdam, Amsterdam Infection \& Immunity Institute, Amsterdam, the Netherlands

${ }^{6}$ Department of Medicine, Weill Cornell Medicine, New York, New York

+TJK and DC made equal contributions to this paper

${ }^{\#}$ Current address: Antibody Research \& Technology, Genmab Inc.

CORRESPONDING AUTHOR

John P. Moore, PhD

jpm2003@med.cornell.edu

212-746-4462

\section{SUGGESTED CITATION}

Ketas TJ, Chaturbhuj D, Cruz Portillo VM, Francomano E, Golden E, Chandrasekhar S, Debnath G, Diaz-Tapia R, Yasmeen A, Kramer KD, Munawar T, Leconet W, Zhao Z, Brouwer PJM, Cushing MM, Sanders RW, Cupo A, Klasse PJ, Formenti SC, Moore JP. Antibody Responses to SARSCoV-2 mRNA Vaccines are Detectable in Saliva. Pathogens and Immunity. 2021;6(1):116-134. doi: 10.20411/pai.v6i1.441. 


\section{ABSTRACT}

The approved Pfizer and Moderna mRNA vaccines are well known to induce serum antibody responses to the SARS-CoV-2 Spike (S)-protein. However, their abilities to elicit mucosal immune responses have not been reported. Saliva antibodies represent mucosal responses that may be relevant to how mRNA vaccines prevent oral and nasal SARS-CoV-2 transmission. Here, we describe the outcome of a cross-sectional study on a healthcare worker cohort (WELCOME-NYPH), in which we assessed whether IgM, IgG, and IgA antibodies to the S-protein and its receptor-binding domain (RBD) were present in serum and saliva samples. Anti-S-protein IgG was detected in 14/31 and 66/66 of saliva samples from uninfected participants after vaccine doses-1 and -2, respectively. IgA antibodies to the S-protein were present in 40/66 saliva samples after dose 2. Anti-S-protein IgG was present in every serum sample from recipients of 2 vaccine doses. Vaccine-induced antibodies against the RBD were also frequently present in saliva and sera. These findings may help our understanding of whether and how vaccines may impede SARS-CoV-2 transmission, including to oral cavity target cells.

\section{INTRODUCTION}

Vaccines are critical for curtailing the COVID-19 pandemic $[\underline{1}, \underline{2}]$. In the United States, 2 highly protective mRNA vaccines are available: BNT162b2 (Pfizer/BioNTech) and mRNA-1273 (Moderna) $[\underline{3}, \underline{4}]$. These vaccines induce antibodies to the SARS-CoV-2 S-protein, including neutralizing antibodies (NAbs) predominantly directed against the receptor binding domain [ $\underline{1}-\underline{4}$ ]. Serum NAbs are induced at modest levels within $\sim 1$ week of dose 1 and strongly boosted by dose 2 at 3 (Pfizer) or 4 weeks (Moderna) [ $\underline{3}, \underline{4}]$. SARS-CoV-2 is typically transmitted nasally or orally and infects cells in the mucosae of the respiratory and gastrointestinal tracts [ $\underline{5}-\underline{8}]$. Although serum NAbs are a correlate of protection against COVID-19 $[\underline{9}, \underline{10}]$, mucosal antibodies might directly prevent or limit virus acquisition by the nasal, oral, and conjunctival routes $[\underline{5}-\underline{8}, \underline{11}]$. Indeed, antibodies in the respiratory tract or oral cavity have been deemed important to protection against a human-to-human transmitted hantavirus, influenza virus, and respiratory syncytial virus [1214]. Vaccines based on adenovirus vectors can induce mucosal immunity to the latter 2 viruses $[\underline{13}, \underline{14}]$. Whether mRNA vaccines induce mucosal immunity requires more study [9]]. We report that antibodies to the $\mathrm{S}$-protein are present in saliva samples from vaccinated healthcare workers (HCW). Within 1-2 weeks after their second dose, 53/53 and 13/13 recipients of the Pfizer and Moderna vaccines, respectively, had saliva S-protein IgG antibodies, while IgA was detected in a substantial proportion. These observations may be relevant to vaccine-mediated protection from SARS-CoV-2 infection and disease.

\section{METHODS}

\section{Patients and Data Sources}

The NYP-WELCOME (WEilL COrnell Medicine Employees) trial was initiated on June 16, 2020 at Weill Cornell Medicine (WCM) and New York Presbyterian Hospital (NYP). The aim of the trial is to study the diverse COVID-19 outcomes (from infection to resolution or death and before, during, and after vaccination) among an exposed population in Manhattan, consisting of NYP-Weill Cornell Medicine, asymptomatic, volunteer HCWs. Sequential specimens and questionnaires are collected twice monthly for 3 months and then monthly for 2 years. Samples are collected within the Cornell Clinical \& Translational Science Center and stored in the Institutional Biobank. As of 
4/1/21, the biobank contains 12,836 trial specimens: PBMCs, saliva, stool, urine, plasma, serum and nasopharyngeal (NP) swab extracts. Here, we used serum and saliva samples only.

NYP-WELCOME inclusion criteria are a completed Informed Consent; age $\geq 18$ years old; currently working at Weill Cornell Medicine as a New York Presbyterian or Weill Cornell Medicine employee; able to speak and read English; at risk for COVID-19 through working in 1 or more of the following sites: intensive care unit; emergency department; emergency services; COVID-19 hospital unit/ward; respiratory services; COVID-19 testing location; inpatient hospital unit/ area with potential COVID-19 cases; WCM-staffed outpatient area; WCM research laboratory; or by interacting, even occasionally, with WCM clinical or research faculty. Exclusion criteria are a prior diagnosis of COVID-19 infection by a commercially available test; participation in a COVID-19 prophylaxis trial within 30 days of consent; respiratory or gastrointestinal illness with new-onset fever (temperature $>100.4^{\circ} \mathrm{F}$ ); ongoing cough or dyspnea within 14 days; pulse oximeter $<94 \%$.

The WCM Institutional Review Board approved the WELCOME trial (Weill Cornell Medicine Employees) on 6.3.2020 with protocol number 20-04021831. Silvia C. Formenti MD is the Principal Investigator. Demographic information on the NYP-WELCOME trial is summarized in the Results section.

\section{Sample processing}

Blood was processed into serum that was heat-inactivated at $56^{\circ} \mathrm{C}$. Nonidet-P40 (NP40) non-ionic detergent was added to saliva samples to a final concentration of $0.05 \%$ (vol/vol), both to inactivate SARS-CoV-2 and as a preservative [15]. Saliva extracts were sterilely passed through a $22 \mu \mathrm{m}$ filter, before addition of protease inhibitors to inhibit sample degradation. Inhibitor sources and final concentrations were Aprotinin, $8.5 \mu \mathrm{g} / \mathrm{mL}$ (Sigma Aldrich); phenylmethanesulfonyl fluoride, 5.9mM (Sigma-Aldrich 93482); and sodium orthovanadate, 1.2mM (Sigma-Aldrich S6508). Processed saliva samples were stored at $-20^{\circ} \mathrm{C}[\underline{16}]$. In pilot experiments, we confirmed that NP40 and the aforementioned protease inhibitors had no effect on anti-S-protein titers derived using heat-inactivated saliva samples or the CR3022 anti-RBD MAb. The antibody titers were also unaffected when saliva samples were subjected to 3 freeze/thaw cycles.

\section{S-protein and RBD-protein production}

The expression construct for the pre-fusion, S2-P stabilized SARS-CoV-2 S-Foldon-StreptagII $\mathrm{S}$-protein ectodomain was derived as follows. The gene encoding residues 1-1138 from the Wuhan-Hu-1 strain (Genbank MN908947.3) was modified by introducing proline substitutions at residues 986 and 987 and a GGGG-substitution at residues 682-685 (Furin cleavage site). The modified gene was cloned into a pPPI4 plasmid containing a T4 trimerization domain followed by Strep-tag ${ }^{\oplus}$ II [17]. For a $1 \mathrm{~L}$ transfection of ExpiCHO cells $\left(6 \times 10^{6}\right.$ per $\left.\mathrm{mL}\right), 800 \mu \mathrm{g}$ of plasmid, $1.6 \mathrm{~mL}$ of FectoPRO reagent (Polyplus-transfection SA) and $500 \mu \mathrm{L}$ of FectoPRO booster were added to $40 \mathrm{~mL}$ of Opti-MEM (Thermo Fisher Scientific). Culture supernatants were harvested 3 days post-transfection, centrifuged for 1 hour at $6900 \mathrm{~g}$ and passed through a $0.2 \mu \mathrm{m}$ filter (Thermo Fisher Scientific). BioLock-Biotin blocking solution (IBA Lifesciences) was added before the treated supernatants were passed over StrepTactin ${ }^{\mathrm{TM}}$ Sepharose resin (GE Healthcare). S-proteins were eluted in $2.5 \mathrm{mM}$ desthiobiotin in $100 \mathrm{mM}$ Tris- $\mathrm{HCl}, 150 \mathrm{mM} \mathrm{NaCl}, 1 \mathrm{mM}$ EDTA, pH 8.0, dia- 
lyzed into PBS and concentrated using Vivaspin protein spin columns with a $100 \mathrm{kDa}$ molecular weight cutoff (GE Healthcare). Protein concentrations were determined using the BCA protein assay kit (Thermo Fisher). Purity was assessed on a $4 \%$ to $16 \%$, Bis-Tris Native PAGE gel system (Invitrogen). For SDS-PAGE, purified proteins were denatured with $0.1 \mathrm{mM}$ dithiothreitol (DTT) before loading onto a 4\% to $12 \%$ Bis-Tris Gel NuPAGE gel (Invitrogen).

S-proteins from the 229E, HKU1, NL63, and OC43 endemic CoVs were also expressed in ExpiCHO cells and purified using Strep Tactin ${ }^{\text {Tm }}$ Sepharose resin (GE Healthcare), as described above. The HCoV-NL63-S-foldon-StreptagII and HCoV-229E-S-foldon-S-StreptagII plasmids were generated by Philip Brouwer (AMC), Amsterdam, while the HCoV-OC43-S-StreptagII and HCoV-HKU1-S-StreptagII plasmids were provided by Gabriel Ozorowski (Scripps Research Institute, La Jolla).

The SARS-CoV-2-RBD-StrepII expression construct was a gift from Dr. Lakshamanane Premkumar (University of North Carolina) and has been described previously [18]. The construct was expressed and purified as described for the S-protein, except that the dialyzed RBD-protein was concentrated using a spin column with a $10 \mathrm{kDa}$ molecular weight cutoff.

\section{ELISA procedures}

The assay to quantify SARS-CoV-2 S-protein antibodies was modified from one described previously [19]. For serum samples, S-proteins $(200 \mathrm{ng}$ in $100 \mu \mathrm{L})$ were coated overnight onto 96-well plates at $4^{\circ} \mathrm{C}$. After 3 washes with PBS/0.05\% Tween-20 (PBST), the wells were blocked for 1 hour with $4 \%$ (w/vol) powdered milk/PBS (150 $\mu \mathrm{L} /$ well). Serum was initially diluted $1 / 100$ in PBS containing 4\% milk and 20\% sheep serum, serially diluted as needed, and added to wells for 1 hour. Bound antibodies were detected using goat anti-human horse radish peroxidase (HRP)-conjugated antibodies: anti-IgA from Southern Biotech (2050-05), diluted 1/3000 in 4\% milk/PBS; anti-IgG from Jackson ImmunoResearch (109-035-008), diluted 1/5000; and anti-IgM from Jackson ImmunoResearch (109-035-043), diluted 1/5000. After washing, $50 \mu \mathrm{L}$ of HRP substrate (Thermo Scientific 34029) was added to each well for 3 minutes. Color development was terminated with $0.3 \mathrm{~N}$ sulfuric acid, and plates were read at $450 \mathrm{~nm}$ using an EnSpire instrument (Perkin Elmer).

To assay saliva samples, modifications were made to increase assay sensitivity and conserve sample volume. The 96-well plates were replaced by 384-well plates (Thermo Scientific 464718). Incubation volumes were correspondingly smaller $(10 \mu \mathrm{L} /$ well $)$ except for the blocking buffer (100 $\mu \mathrm{L} /$ well). The amount of S-protein (SARS-CoV-2 or, when appropriate, from the endemic CoVs) added to wells was $100 \mathrm{ng}$ in $10 \mu \mathrm{L}$, to create a higher coating density. The HRP substrate volume was increased to $25 \mu \mathrm{L} /$ well and the reaction time lengthened to 15 minutes. Accordingly, the colorimetric signals derived from the saliva and serum assays are not directly comparable.

ELISAs to quantify anti-RBD antibodies were performed as described for S-proteins. The $\mathrm{RBD}$-proteins were coated at $100 \mathrm{ng}$ in $100 \mu \mathrm{L}$ for testing sera and $100 \mathrm{ng}$ in $10 \mu \mathrm{L}$ for saliva. ELISA-derived net OD450 values for 4-fold dilutions of saliva and 100-fold dilutions of sera were determined by subtracting background values from wells containing no S-protein. The cut-off for positive antibody detection was set to a net OD450 of 0.300 . This value corresponds to 6-times the average net OD450 derived from negative samples (324/327 below cut-off, yielding a specificity of 99\%). Net OD450 values were plotted longitudinally for each study participant. For 5 
vaccinated participants (Pfizer, $n=3$; Moderna, $n=2$ ), no saliva sample collected at any timepoint could be processed successfully because the ELISA background values (no S-protein) were unacceptably high. Thus, for these samples the OD450 values were $>0.400$, which was twice the median background for all samples tested. These 5 participants were excluded from the analyses described here. Twenty additional samples from 13 different participants were also excluded for the same reason, although in each case samples from other timepoints could be processed successfully and were included in the analyses.

To assess the specificity and sensitivity of IgA detection, purified human IgG (Sigma 14506), purified Secretory IgA (SIgA) (BioRad PHP133), or recombinant IgA1 lambda (BioRad HCA172) were coated onto ELISA plates (Corning 3690) and probed with goat anti-Human IgA-HRP (Southern Biotech 2050-05).

\section{RESULTS}

\section{The NYP-WELCOME trial}

The NYP-WELCOME trial is described in the Methods section. To date (4/1/21), 97 participants have completed 605 study visits, with 94 remaining in the trial (3 withdrew at various times). The cohort includes 72 females and 22 males. Of the 94 participants, 61 are white, 9 are Asian, 2 are Black, 18 self-reported as "Other", and 4 declined to provide information. The median age of cohort members is 39.5 years.

Seven participants were SARS-CoV-2-infected before joining the trial. Two more became infected during the trial, as determined by a positive NP swab RT-PCR test, and 1 more as judged by positivity for serum S-protein antibodies at multiple time-points. Of the 10 infected people, 8 were later vaccinated.

Pfizer and Moderna mRNA vaccines became available at NYP-WCM after December 15th, 2020. As of 4/1/21, 85/94 NYP-WELCOME participants have received at least $1 \mathrm{mRNA}$ vaccine dose (Pfizer, $\mathrm{n}=68$ participants; Moderna, $\mathrm{n}=17$ ). One male participant received an experimental vaccine candidate (Novavax) or a placebo, at which point he was excluded from this study. Of 85 mRNA vaccine recipients, 66 were female and 19 male. As outlined below, we successfully detected S-protein antibodies in saliva and serum samples from both 55 Pfizer and 14 Moderna uninfected vaccine recipients. Among these 69 individuals, samples were available from 66 after 2 doses while 2 Pfizer and 1 Moderna vaccine recipients provided samples only after the first dose. 


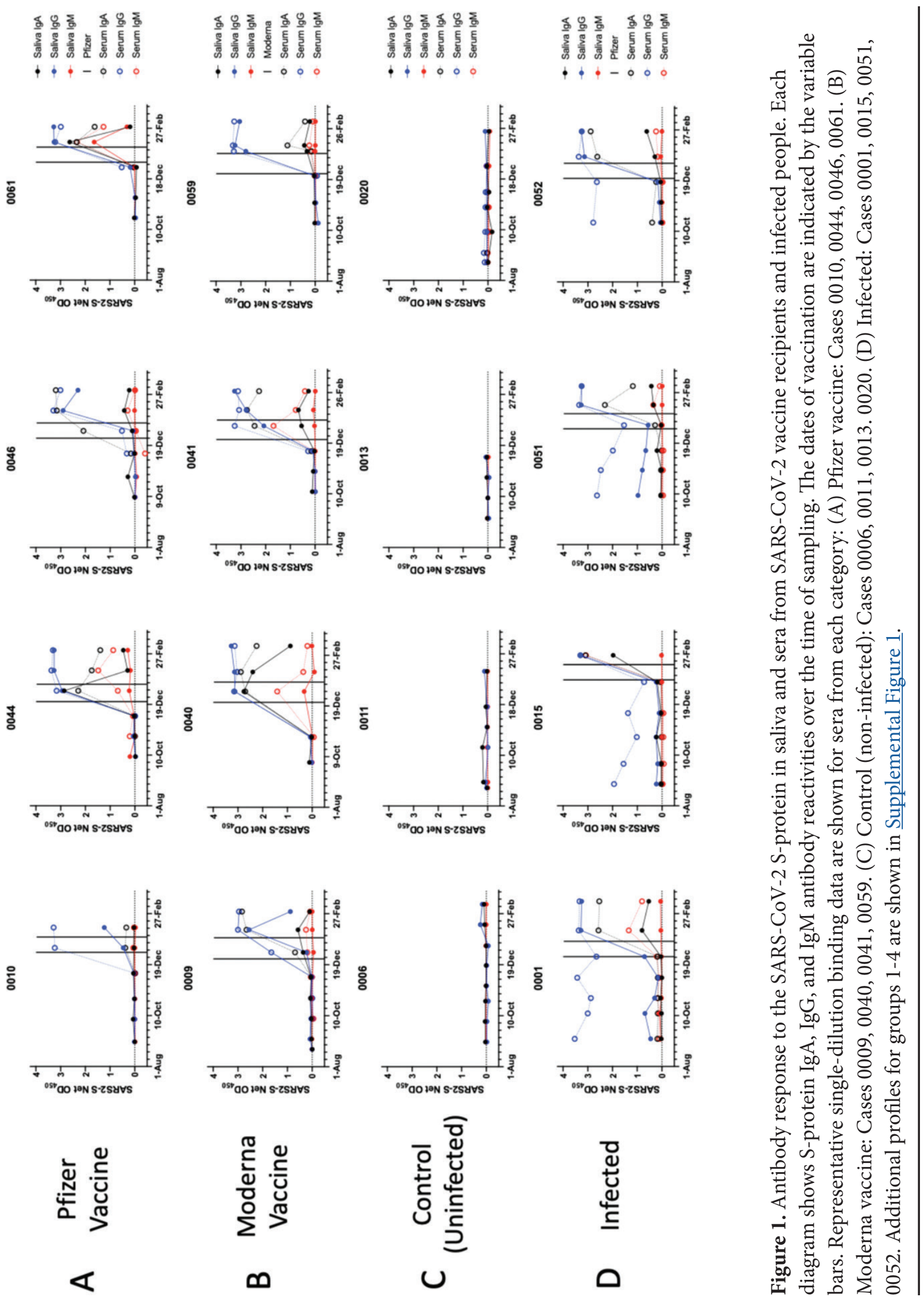




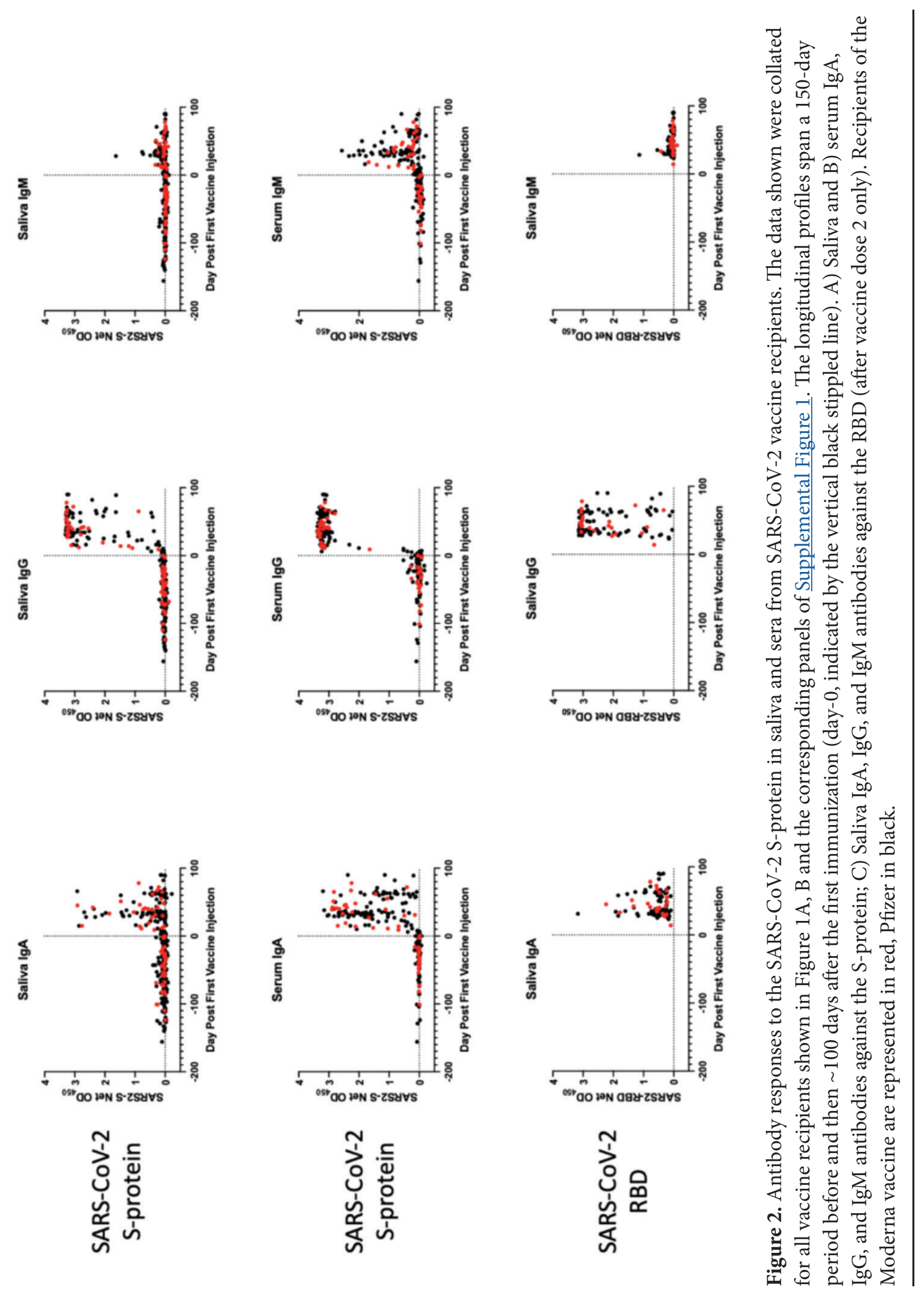




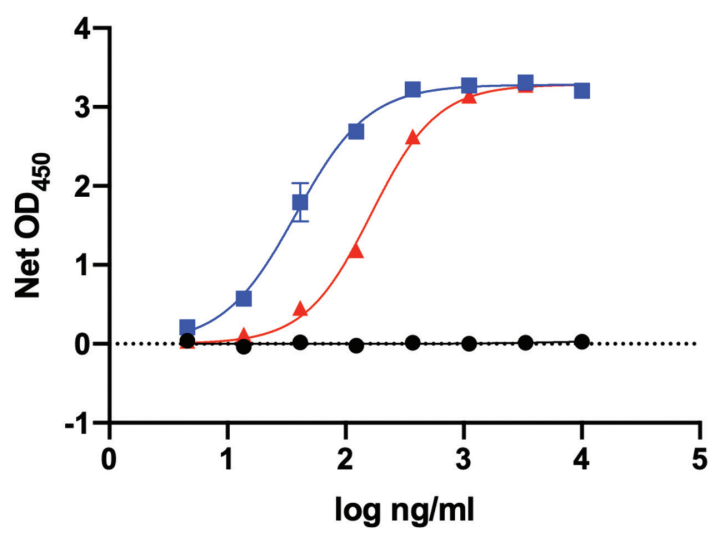

$$
\begin{aligned}
& - \text { IgG Standard } \\
& - \text { SIgA Standard } \\
& - \text { IgA Standard }
\end{aligned}
$$

Figure 3. Specificity and sensitivity of IgA detection. Purified human IgG, purified SigA, and recombinant, dimeric IgA lambda were coated onto ELISA plates and detected with the same goat anti-human IgAHRP conjugate used in the assays to detect saliva and serum IgA S-protein antibodies. The plot shows net OD450 values (+/- SEM) as a function of the logarithmic concentrations of the 3 antibodies added to the ELISA wells during the coating stage.

\section{Detection of antibodies to the SARS-CoV-2 S-protein and RBD in saliva and serum}

We assessed the development of antibody responses to the SARS-CoV-2 S-protein in serum and saliva samples from mRNA-vaccinated HCWs. We were able to process saliva samples successfully from the majority of trial participants (Table 1) and performed antibody assays on sera from the same subset of individuals, for comparison. Longitudinal profiles for S-protein IgA, IgG, and IgM saliva and serum responses in selected individuals from Groups 1-4 are shown in Figure 1. A collated data set for Groups 1 and 2 is presented in Figure 2, which also includes data on saliva antibody responses to the SARS-CoV-2 RBD-protein (Figure 2C). The profiles selected for display in Figure 1 are those for which sample collection dates were well matched to when the vaccines were administered. Additional longitudinal profiles are shown as Supplemental Figure 1. Recipients of the Pfizer and Moderna vaccines form Groups 1 and 2, respectively (Figure 1A, B; Supplemental Figure 1A, B). For comparison, we also studied 2 other sub-groups of participants. Group-3 members were SARS-CoV-2 uninfected $(\mathrm{n}=7)$ (Figure 1C, Supplemental Figure 1C), while Group 4 included people who had recovered from COVID-19 or became infected during participation in the NYP-WELCOME trial $(n=10)$. Among Group-4 members, 8 were vaccinated (Figure 1D, Supplemental Figure 1D).

The net $\mathrm{OD}_{450}$ values from the ELISAs were derived from saliva diluted 1/4 and sera diluted 1/100. This difference together with others described in Methods mean that the signals from the saliva and serum ELISAs are not directly comparable. The saliva assay is the more sensitive of the 2 (see Figure 5). Note that antibody concentrations in saliva are generally much lower than in sera (see Figure 5). Differences in coating concentrations also affect the direct comparability of assays performed using the SARS-CoV-2 S-protein and its RBD. 
Table 1. Saliva samples successfully processed from NYP-WELCOME cohort members

\begin{tabular}{|l|c|c|c|}
\hline & $\begin{array}{c}\text { Number } \\
\text { vaccinated }\end{array}$ & $\begin{array}{c}\text { Saliva samples analyzed } \\
\text { between dose 1 and dose 2 }\end{array}$ & $\begin{array}{c}\text { Saliva samples } \\
\text { analyzed after dose 2 }\end{array}$ \\
\hline $\begin{array}{l}\text { Group 1 } \\
\text { Pfizer Vaccine }\end{array}$ & 55 & 24 & 53 \\
\hline $\begin{array}{l}\text { Group 2 } \\
\text { Moderna Vaccine }\end{array}$ & 14 & 7 & 13 \\
\hline
\end{tabular}

The IgA-detection conjugate is specific for IgA and does not cross-react with IgG (Figure 3). Both SIgA and recombinant, dimeric IgA standards are detected, but for simplicity we routinely refer to what we have assayed as being IgA. The $\sim 5$-fold more sensitive detection of SigA could arise from coating efficiency differences vs IgA under the ELISA conditions used and/or conjugate properties (Figure 3).

The NYP-WELCOME cohort was not established as a vaccine study, so there was no coordination between the dates of vaccine administration and the approximately monthly sample collection dates. Hence, samples were not available for some participants in the 3- (Pfizer) and 4-week (Moderna) period between the 2 vaccine doses (Table 1). Overall, however, sufficient samples were available from before and after each vaccination to allow conclusions to be drawn.

The longitudinal profiles (Figures 1A, B; Supplemental Figure 1A, B) and collated data (Figure 2, Table 2) show that the Pfizer and Moderna vaccines rapidly and consistently induce S-protein-specific IgG and IgA in both saliva and sera, with IgM occasionally detected. The proportions of vaccinated individuals with saliva and serum IgG, IgA, and IgM S-protein antibodies after the first and second doses are summarized in Table 2. Antibody responses against the SARS-CoV-2 RBD-protein were also determined for all Group 1 and Group 2 samples collected after the second vaccine dose (Figure 2C, Table 2).

Saliva samples from 31 individuals at various times during the inter-dose period were successfully processed, with S-protein IgG detectable in 14 of them during this period (Figure 1A, B; Supplemental Figure 1A, B, Table 2). Two Pfizer and 1 Moderna vaccine recipients provided saliva samples after dose 1 but had not received their second dose (Supplemental Figure 1A, B $)$. After dose 2, 66 vaccine recipients (53 Pfizer, 13 Moderna) were positive for saliva S-protein IgG, with IgA antibodies frequently but not uniformly detected and IgM present only rarely. All vaccine recipients had serum IgG and IgA antibodies to the S-protein after dose 2, and most also had IgM. Anti-RBD IgG antibodies were detected in $100 \%$ of saliva and serum samples after dose 2, while IgA was detected frequently and IgM occasionally (Figure 2C, Table 2).

In contrast to the response to vaccination, S-protein antibodies were not detectable in saliva samples from uninfected control individuals (Figure 1C, Supplemental Figure 1C). Trial participants who became virus-infected before or during the trial did, however, have S-protein IgG in their saliva, although these infection-elicited responses tended to wane over a multi-month period. IgA antibodies were occasionally detected at lower levels in these saliva samples (Figure 1D, Supplemental Figure 1D). Observations of S-protein IgG and IgA in saliva from SARS-CoV-2 infected people 
are consistent with previous reports $[\underline{5}-\underline{8}, \underline{20}-\underline{22}]$. When 8 infected individuals $(0001,0014,0015$, 0037, 0051, 0052, 0053, and 0074) were vaccinated, their saliva and serum S-protein IgA and IgG reactivities and, in 1 case also IgM, were rapidly boosted (Figure 1D and Supplemental Figure 1D).

Table 2. Proportions of vaccinated individuals with saliva and serum IgG, IgM, and IgA S-protein antibodies after the first and second doses

\begin{tabular}{|c|c|c|c|c|c|c|}
\hline \multicolumn{7}{|c|}{ Group 1: Pfizer vaccine } \\
\hline & \multicolumn{2}{|c|}{$\operatorname{IgA}$} & \multicolumn{2}{|c|}{ IgG } & \multicolumn{2}{|c|}{$\operatorname{IgM}$} \\
\hline & Saliva & Serum & Saliva & Serum & Saliva & Serum \\
\hline $\begin{array}{l}\text { S-protein } \\
\text { After dose } 1\end{array}$ & $\begin{array}{c}4 / 24 \\
(17 \%)\end{array}$ & $\begin{array}{c}9 / 24 \\
(38 \%)\end{array}$ & $\begin{array}{c}8 / 24 \\
(33 \%)\end{array}$ & $\begin{array}{l}13 / 24 \\
(54 \%)\end{array}$ & $\begin{array}{l}0 / 24 \\
(0 \%)\end{array}$ & $\begin{array}{c}4 / 24 \\
(17 \%)\end{array}$ \\
\hline $\begin{array}{l}\text { S-protein } \\
\text { After dose } 2\end{array}$ & $\begin{array}{l}29 / 53 \\
(55 \%) \\
\end{array}$ & $\begin{array}{c}52 / 52 \\
(100 \%)\end{array}$ & $\begin{array}{c}53 / 53 \\
(100 \%)\end{array}$ & $\begin{array}{c}52 / 52 \\
(100 \%)\end{array}$ & $\begin{array}{c}9 / 53 \\
(17 \%) \\
\end{array}$ & $\begin{array}{l}37 / 52 \\
(71 \%) \\
\end{array}$ \\
\hline $\begin{array}{l}\text { RBD } \\
\text { After dose } 2\end{array}$ & $\begin{array}{l}44 / 53 \\
(83 \%)\end{array}$ & $\begin{array}{l}39 / 51 \\
(76 \%)\end{array}$ & $\begin{array}{c}53 / 53 \\
(100 \%)\end{array}$ & $\begin{array}{c}51 / 51 \\
(100 \%)\end{array}$ & $\begin{array}{l}2 / 53 \\
(4 \%)\end{array}$ & $\begin{array}{l}28 / 51 \\
(55 \%)\end{array}$ \\
\hline
\end{tabular}

Group 2: Moderna vaccine

\begin{tabular}{|l|c|c|c|c|c|c|}
\hline & \multicolumn{2}{|c|}{ IgA } & \multicolumn{2}{c|}{ IgG } & \multicolumn{2}{c|}{ IgM } \\
\hline & Saliva & Serum & Saliva & Serum & Saliva & Serum \\
\hline S-protein & $5 / 7$ & $7 / 7$ & $6 / 7$ & $7 / 7$ & $1 / 7$ & $5 / 7$ \\
After dose 1 & $(71 \%)$ & $(100 \%)$ & $(86 \%)$ & $(100 \%)$ & $(14 \%)$ & $(71 \%)$ \\
\hline S-protein & $11 / 13$ & $13 / 13$ & $13 / 13$ & $13 / 13$ & $1 / 13$ & $8 / 13$ \\
After dose 2 & $(85 \%)$ & $(100 \%)$ & $(100 \%)$ & $(100 \%)$ & $(8 \%)$ & $(62 \%)$ \\
\hline RBD & $10 / 13$ & $13 / 13$ & $13 / 13$ & $13 / 13$ & $1 / 13$ & $6 / 13$ \\
After dose 2 & $(77 \%)$ & $(100 \%)$ & $(100 \%)$ & $(100 \%)$ & $(8 \%)$ & $(46 \%)$ \\
\hline
\end{tabular}

The denominator values for saliva in this table are those recorded in Table 1. The antigen used to detect the antibodies (S-protein or RBD) is indicated. One serum sample from the Pfizer vaccine group was not available.

\section{S-protein IgA in saliva from an uninfected individual, pre-vaccination}

Pre-vaccination saliva samples from one participant, 0022, who had no documented evidence of SARS-CoV-2 infection and was seronegative for S-protein antibodies, consistently contained S-protein IgA but not IgG. After vaccination, saliva IgA and IgG levels both increased in participant 0022 (Figure 4A). One explanation is that the saliva IgA against the SARS-CoV-2 S-protein may reflect virus exposure that did not lead to systemic infection but was sufficient to trigger a mucosal immune response. There are reports of mucosal anti-S-protein IgA in uninfected, seronegative individuals $[\underline{23}, \underline{24}]$. However, we explored an alternative explanation by testing the 0022 saliva and serum samples against S-proteins from the 229E, HKU1, NL63, and OC43 viruses (Figure 4B). IgAs against all 4 of these CoV S-proteins were detected in saliva, as were the corresponding serum IgGs. Anti-S-protein saliva IgG and serum IgA to the endemic CoVs were also observed although less consistently (Figure 4B). A cross-reactive antibody response to an endem- 
ic CoV infection seems the more likely explanation for the saliva IgA detected in participant 0022 using the SARS-CoV-2 S-protein (Figure 4A, B).

A

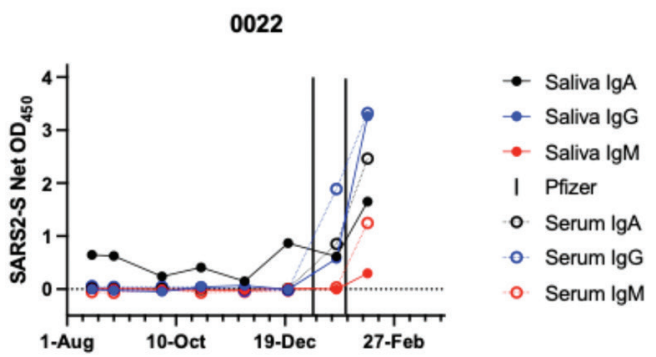

B
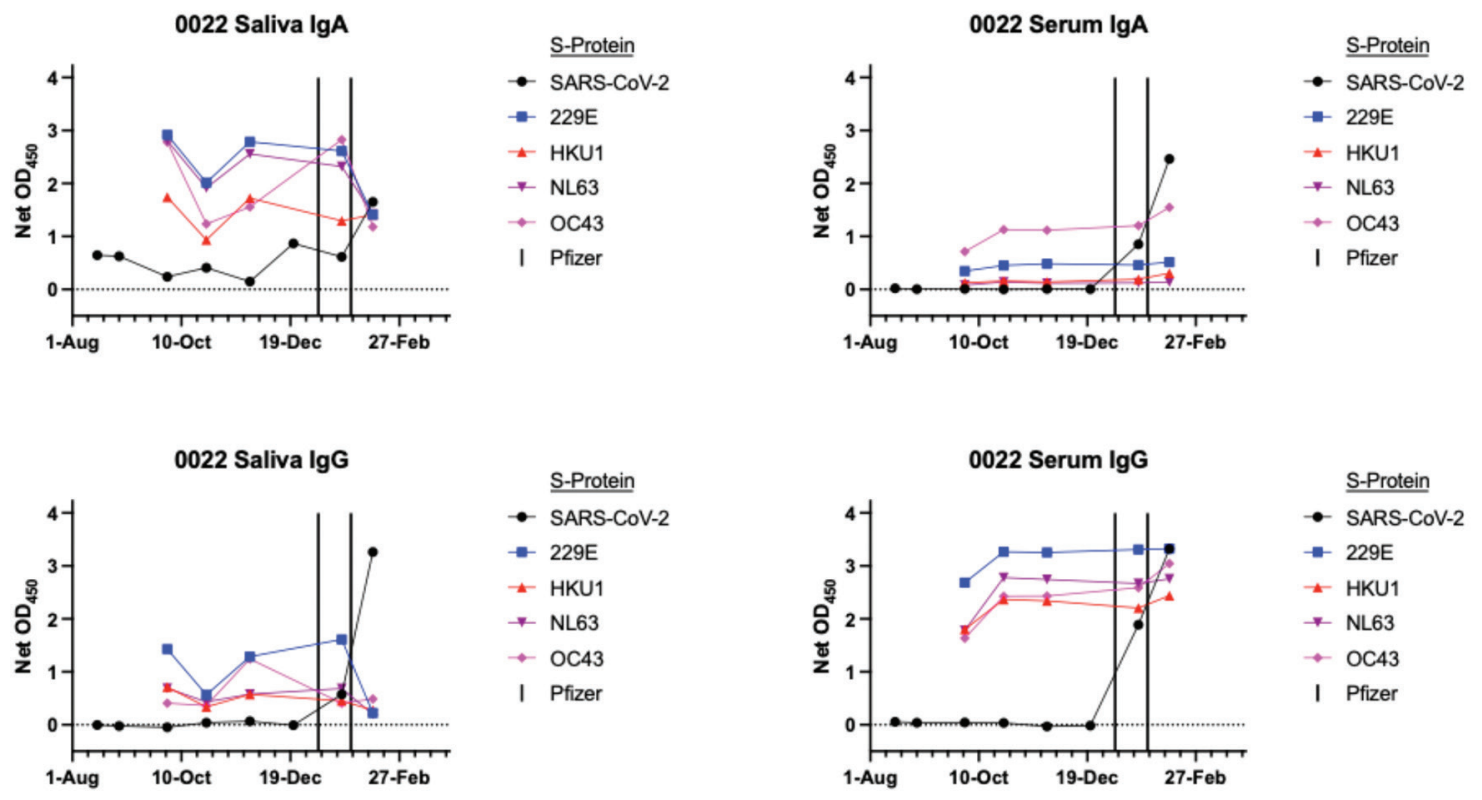

Figure 4. Antibody response to the common cold CoV S-proteins in saliva and sera from participant 0022. A) The format of this panel is the same as Figure 1 and shows data derived using the SARS-CoV-2 S-protein. B) The panels show saliva or serum IgA or IgG antibody responses to S-proteins from the endemic CoVs 229E, HKU1, NL63, and OC43, in comparison to SARS-CoV-2, as indicated. 


\section{Comparative magnitude of anti-S-protein responses in saliva and sera}

The data for saliva and serum S-protein antibodies in Figures 1 and 2 are derived from ELISAs performed under different conditions (S-protein coating amounts and sample dilutions; see Methods section). The saliva assay is the more sensitive of the 2, and hence the data plots should not be interpreted as indicating there are quantitatively similar IgA and IgG reactivities in the 2 fluids. To gain an insight into the relative magnitudes of the saliva and serum responses, we titrated a serum sample from an infected individual (D56) and sera from 2 participants who had each received 2 Pfizer vaccine doses (Cases 0003 and 0007), using the saliva ELISA format, alongside saliva samples from the same individuals (Figure 3). Judged by the displacements of the titration curves, we estimate that the end-point titers of S-protein IgA and IgG antibodies present in saliva are $\sim 1000$-fold and $\sim 10,000$ fold lower, respectively, than in serum (Figure 5 ). Note that infection serum D56 neutralized SARS-CoV-2 with an $\mathrm{ID}_{50}$ titer of 900 in our SARS-CoV-2 pseudovirus-based neutralization assay [17]. The much lower S-protein antibody reactivities present in saliva are below the detection limit for that assay. However, we consistently detected IgA antibodies to the SARS-CoV-2 RBD in saliva samples after the second vaccine dose (Figure 2C, Table 2). These RBD-reactive antibodies may be capable of virus neutralization.
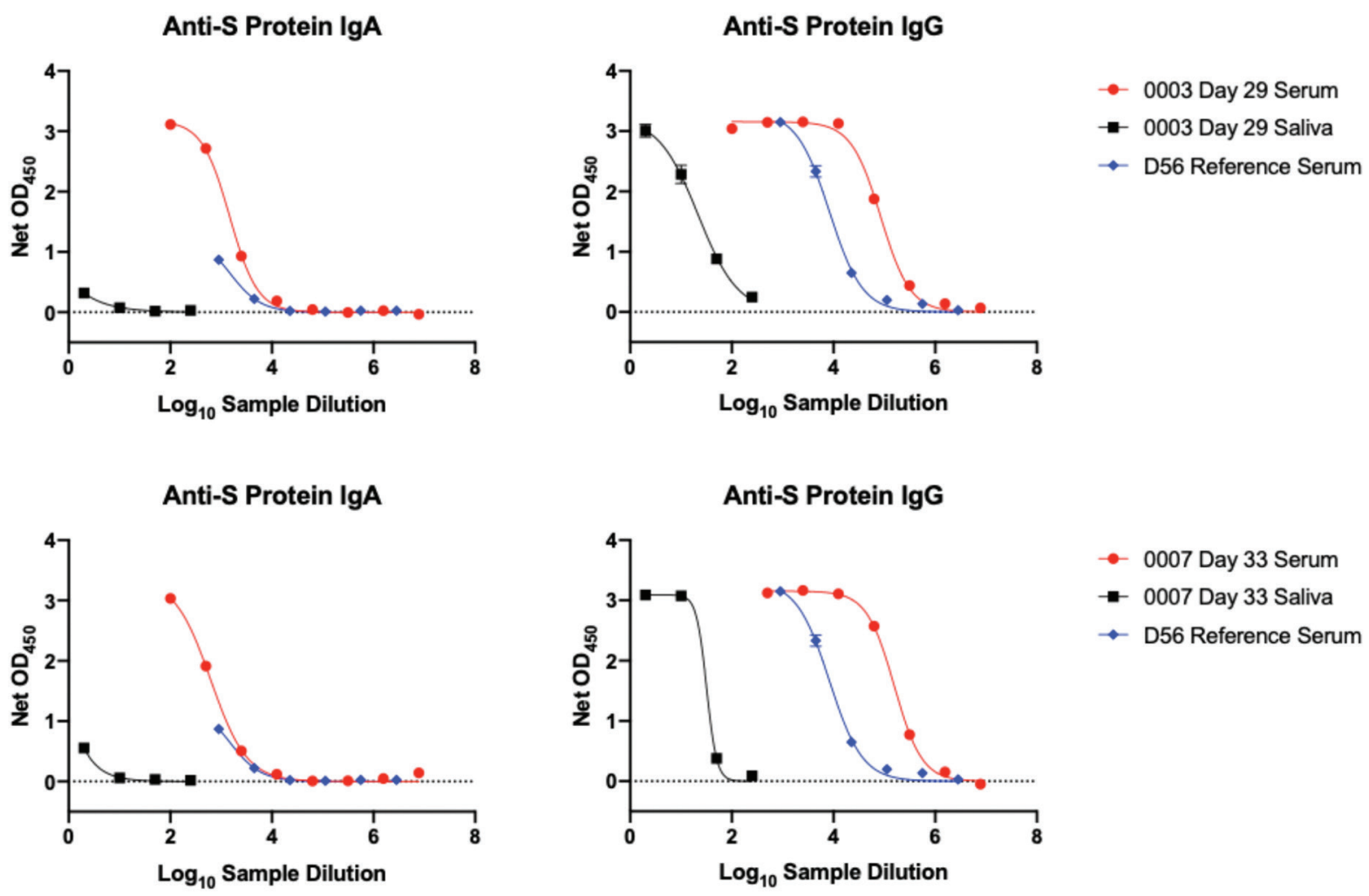

Figure 5. Relative antibody reactivities with S-protein in saliva and sera. A reference serum from a SARSCoV-2 infected person (D56, not part of the NYP-WELCOME cohort; in blue) and serum (in red) and saliva (in black) samples from 2 recipients of 2 doses of the Pfizer vaccine (0003, day-29, top row; 0007, day-33, bottom row) were titrated under the conditions of the ELISA used to detect IgA and IgG in saliva. The displacement of the serum and saliva titration curves suggest that the S-protein IgA and IgG endpoint titers in saliva are $\sim 1000$-fold and $\sim 10,000$-fold lower than in sera, respectively. 


\section{DISCUSSION}

We show that mRNA vaccines induce not just systemic serum anti-S-protein responses but also IgG and, to a lesser extent, IgA antibodies that are detectable in saliva. The assay we used recognizes dimeric IgA with and without the J-chain and secretory component; ie, SIgA + dIgA (Figure 3). Antibodies in saliva are known to be dominated by SIgA and IgG. Local plasma cells in the stroma of salivary glands secrete $\operatorname{dIgA}$, which traffics through mucosae by interacting with the polymeric Ig receptor. Typically, $\sim 95 \%$ of salivary IgA is in the SIgA form. In contrast, IgG in saliva largely originates from plasma, by transudation from the gingival blood circulation [25-27]. IgM, also derived from plasma, is found at lower levels. In healthy people, the total concentrations in saliva are $\sim 150 \mu \mathrm{g} / \mathrm{ml}$ for SIgA, $\sim 15 \mu \mathrm{g} / \mathrm{ml}$ for IgG, and $\sim 5 \mu \mathrm{g} / \mathrm{ml}$ for IgM. In contrast, serum concentrations are $\sim 1000$-fold higher for IgG and $\sim 100$-fold for total IgA $[25,27]$. Because saliva IgG is mostly transudated from blood, it is probable that the anti-S-protein content of saliva largely reflects what is present in serum, albeit in lower amounts. The limited saliva volumes that were collected from the vaccine recipients precluded a more detailed investigation of what IgA forms contribute to the overall saliva anti-S response.

Could vaccine- or infection-induced salivary and, by extension, nasopharyngeal antibodies prevent or limit SARS-CoV-2 infection at the principal portals of entry-the mouth and nose? Our data raise that possibility but cannot provide a definitive answer. Additional studies in this area are justified, particularly now that key target cells for SARS-CoV-2 infection in the oral cavity have been identified [ $[$ ]. A report on SARS-CoV-2 infection in rhesus macaques shows that virus can still replicate in nasal turbinates even when it is suppressed in the lungs by passively transferred NAbs [2] ]. Assays of vaccine-induced antibodies extracted from NP swabs might provide useful information, although Ig concentrations in tissue sites, eg, intra-mucosal interstitial fluids, may be impossible to measure by swab-sampling and extraction.

There is increasing evidence that SARS-CoV-2 transmission is prevented by vaccination, quite plausibly by vaccine-elicited NAbs $[\underline{4}, \underline{9}, \underline{10}, \underline{29}, \underline{30}]$. Only a subset of antibodies to the S-protein is capable of virus neutralization, principally by binding to epitopes in the RBD and the N-terminal domain $[\underline{31}, \underline{32}]$. Our S-protein ELISA detects both NAbs and non-neutralizing antibodies, and the latter are likely to play little or no role in limiting virus transmission. We did, however, consistently detect antibodies to the RBD in saliva after the second vaccine dose, which suggests that saliva at least has the potential for virus neutralization $[\underline{31}, \underline{32}]$. We cannot confirm this supposition directly, because we have found that saliva components interfere with pseudovirus-based neutralization assays, and hence that it is necessary to purify the Ig fraction. Unfortunately, the saliva volumes collected in the NYP-WELCOME study are much too low for Ig purification to be practical (the protocol was designed in the summer of 2020, well before the present sub-project was contemplated). IgA in saliva from some infected people can neutralize SARS-CoV-2, and neutralizing IgA persists longer in saliva than serum [3] . Of note also is that RBD-specific IgA reactivities in saliva correlated better with the extent of neutralization than the corresponding saliva IgG reactivities, and that RBD-specific IgA reactivities were higher in saliva than serum [21]. Thus, although we found much lower levels of S-protein antibodies in saliva than in sera (Figure 3 ), what is present in saliva may be capable of neutralizing at least some of the incoming virus.

There are reports of uninfected, seronegative HCWs whose mucosal samples (tears, nasal swabs, or saliva) contained anti-S-protein IgA $[\underline{23}, \underline{24}]$. We identified a similar seronegative individual, 
0022, whose saliva contained IgA but, notably, not IgG antibodies to the SARS-CoV-2 S-protein. We also detected antibodies to S-proteins from endemic CoVs (Figure 4). It has been argued that these unusual cases may arise when SARS-CoV-2 exposure did not lead to systemic infection but was sufficient to trigger a mucosal response [1]. T cells reactive with SARS-CoV-2 antigens in some highly exposed but uninfected people have also been reported $[\underline{8}, \underline{24}]$. However, an alternative explanation is that cross-reactivities caused by infections with 1 or more endemic CoVs are responsible. Our data are not sufficient to resolve the uncertainty.

In future studies, it should be possible to determine whether other vaccine designs, such as the Johnson \& Johnson and AstraZeneca adenovirus vectors and the Novavax adjuvanted protein, also induce saliva antibodies, and if so to what extent. Comparing the efficacies of different vaccines at preventing transmission to their abilities to induce mucosal antibody responses may be valuable. For example, a meta-analysis of HIV-1 Env vaccine trials showed that adjuvanted proteins induced mucosal IgG antibodies more consistently than DNA or virus vector vaccines, while IgA antibodies to Env were rarely elicited at mucosal sites by any of the immunogens evaluated [33]).

In conclusion, antibodies against the SARS-CoV-2 S-protein and its RBD are present in every saliva sample from HCWs given 2 doses of Pfizer or Moderna mRNA COVID-19 vaccines. Both IgG and IgA were detected, the former probably representing antibodies transudated from the blood into mucosal sites. While antibodies are present in saliva at much lower levels than serum, it is possible they play a role in preventing or limiting infection when SARS-CoV-2 is transmitted via the nose and mouth. Given the preponderance of these routes in establishing new infections, knowledge of localized antibody responses to vaccination may help us understand their protective mechanisms.

\section{CONFLICT OF INTEREST DISCLOSURES}

None of the authors declares a competing interest.

\section{ACKNOWLEDGEMENTS}

We thank Dr. Elizabeth Ross, Maria Salpietro (Director of the Institutional Biobank), Ashley Sukhu and Biobank staff members for their contributions to the NYP-WELCOME Cohort; and Dr. Julianne Imperato and the Cornell Clinical \& Translational Science Center staff members for their support. We are grateful to Dr. Prem Lakshamanane (University of North Carolina) for providing RBD constructs, and to Dr. Gabriel Ozorowski (Scripps, La Jolla) for endemic CoV S-protein constructs. We appreciate the administrative support of Kathrina Guemo.

\section{SUPPLEMENTARY DATA}

Supplementary materials are available at the Pathogens and Immunity website. Supplementary data may be provided by the authors to benefit the reader. Supplementary data are not copyedited and are the sole responsibility of the authors. Questions or comments related to supplementary materials should be addressed to the corresponding author.

\section{Supplemental Figure 1}




\section{FUNDING SOURCES}

This work was supported by NIH grants P01 AI110657 (Moore) and R01 AI36082 (Moore), and by Weill Cornell Medicine Competitive Research Funding for the NYP-WELCOME trial (Formenti). RWS is a recipient of a Vici fellowship from the Netherlands Organisation for Scientific Research. The funders played no role in the design and conduct of the study; collection, management, analysis, and interpretation of the data; preparation, review, or approval of the manuscript; and decision to submit the manuscript for publication.

\section{REFERENCES}

1. Klasse PJ, Nixon DF, Moore JP. Immunogenicity of clinically relevant SARS-CoV-2 vaccines in nonhuman primates and humans. Sci Adv. 2021;7(12). doi: 10.1126/sciadv. abe8065. PubMed PMID: 33608249; P MCID: PMC7978427.

2. Krammer F. SARS-CoV-2 vaccines in development. Nature. 2020;586(7830):516-27. doi: 10.1038/s41586-020-2798-3. PubMed PMID: 32967006.

3. Baden LR, El Sahly HM, Essink B, Kotloff K, Frey S, Novak R, Diemert D, Spector SA, Rouphael N, Creech CB, McGettigan J, Khetan S, Segall N, Solis J, Brosz A, Fierro C, Schwartz H, Neuzil K, Corey L, Gilbert P, Janes H, Follmann D, Marovich M, Mascola J, Polakowski L, Ledgerwood J, Graham BS, Bennett H, Pajon R, Knightly C, Leav B, Deng W, Zhou H, Han S, Ivarsson M, Miller J, Zaks T, Group CS. Efficacy and Safety of the mRNA-1273 SARS-CoV-2 Vaccine. N Engl J Med. 2021;384(5):403-16. doi: 10.1056/NEJMoa2035389. PubMed PMID: 33378609 ; PMCID: PMC7787219.

4. Polack FP, Thomas SJ, Kitchin N, Absalon J, Gurtman A, Lockhart S, Perez JL, Perez Marc G, Moreira ED, Zerbini C, Bailey R, Swanson KA, Roychoudhury S, Koury K, Li P, Kalina WV, Cooper D, Frenck RW, Jr., Hammitt LL, Tureci O, Nell H, Schaefer A, Unal S, Tresnan DB, Mather S, Dormitzer PR, Sahin U, Jansen KU, Gruber WC, Group CCT. Safety and Efficacy of the BNT162b2 mRNA Covid-19 Vaccine. N Engl J Med. 2020;383(27):2603-15. doi: 10.1056/NEJMoa2034577. PubMed PMID: 33301246; PMCID: PMC7745181.

5. Huang N, Perez P, Kato T, Mikami Y, Okuda K, Gilmore RC, Conde CD, Gasmi B, Stein S, Beach M, Pe-layo E, Maldonado JO, Lafont BA, Jang SI, Nasir N, Padilla RJ, Murrah VA, Maile R, Lovell W, Wallet SM, Bowman NM, Meinig SL, Wolfgang MC, Choudhury SN, Novotny M, Aevermann BD, Scheuermann RH, Cannon G, Anderson CW, Lee RE, Marchesan JT, Bush M, Freire M, Kimple AJ, Herr DL, Rabin J, Grazioli A, Das S, French BN, Pranzatelli T, Chiorini JA, Kleiner DE, Pittaluga S, Hewitt SM, Burbelo PD, Chertow D, Consortium NC-A, Oral HCA, Craniofacial Biological N, Frank K, Lee J, Boucher RC, Teichmann SA, Warner BM, Byrd KM. SARS-CoV-2 infection of the oral cavity and saliva. Nat Med. 2021;27(5):892-903. doi: 10.1038/ s41591-021-01296-8. PubMed PMID: 33767405.

6. Isho B, Abe KT, Zuo M, Jamal AJ, Rathod B, Wang JH, Li Z, Chao G, Rojas OL, Bang YM, Pu A, Christie-Holmes N, Gervais C, Ceccarelli D, Samavarchi-Tehrani P, Guvenc F, Budylowski P, Li A, Paterson A, Yue FY, Marin LM, Caldwell L, Wrana JL, Colwill K, Sicheri F, Mubareka S, Gray-Owen SD, Drews SJ, Siqueira WL, Bar-rios-Rodiles M, Ostrowski M, Rini JM, Durocher Y, McGeer AJ, Gommerman JL, Gingras AC. 
Persistence of se-rum and saliva antibody responses to SARS-CoV-2 spike antigens in COVID-19 patients. Sci Immunol. 2020;5(52). doi: 10.1126/sciimmunol.abe5511. PubMed PMID: 33033173; PMCID: PMC8050884.

7. Russell MW, Moldoveanu Z, Ogra PL, Mestecky J. Mucosal Immunity in COVID-19: A Neglected but Critical Aspect of SARS-CoV-2 Infection. Front Immunol. 2020;11:611337. doi: 10.3389/fimmu.2020.611337. PubMed PMID: 33329607; PMCID: PMC7733922.

8. Sette A, Crotty S. Adaptive immunity to SARS-CoV-2 and COVID-19. Cell. 2021;184(4):861-80. doi: 10.1016/j.cell.2021.01.007. PubMed PMID: 33497610; PMCID: PMC7803150

9. Corbett KS, Nason MC, Flach B, Gagne M, S OC, Johnston TS, Shah SN, Edara VV, Floyd K, Lai L, McDanal C, Francica JR, Flynn B, Wu K, Choi A, Koch M, Abiona OM, Werner AP, Alvarado GS, Andrew SF, Donaldson MM, Fintzi J, Flebbe DR, Lamb E, Noe AT, Nurmukhambetova ST, Provost SJ, Cook A, Dodson A, Faudree A, Greenhouse J, Kar S, Pessaint L, Porto M, Steingrebe K, Valentin D, Zouantcha S, Bock KW, Minai M, Nagata BM, Moliva JI, van de Wetering R, Boyoglu-Barnum S, Leung K, Shi W, Yang ES, Zhang Y, Todd JM, Wang L, Andersen H, Foulds KE, Edwards DK, Mascola JR, Moore IN, Lewis MG, Carfi A, Montefiori D, Suthar MS, McDermott A, Sullivan NJ, Roederer M, Douek DC, Graham BS, Seder RA. Immune Correlates of Protec-tion by mRNA-1273 Immunization against SARS-CoV-2 Infection in Nonhuman Primates. bioRxiv. 2021; doi: 10.1101/2021.04.20.440647. PubMed PMID: 33907752; PMCID: PMC8077626.

10. Francica JR, Flynn BJ, Foulds KE, Noe AT, Werner AP, Moore IN, Gagne M, Johnston TS, Tucker C, Davis RL, Flach B, O’Connell S, Andrew SF, Lamb E, Flebbe DR, Nurmukhambetova ST, Donaldson MM, Todd JM, Zhu AL, Atyeo C, Fischinger S, Gorman MJ, Shin S, Edara VV, Floyd K, Lai L, Tylor A, McCarthy E, Lecouturier V, Ruiz S, Berry C, Tibbitts T, Andersen H, Cook A, Dodson A, Pessaint L, Ry AV, Koutsoukos M, Gutzeit C, Teng IT, Zhou T, Li D, Haynes BF, Kwong PD, McDermott A, Lewis MG, Fu TM, Chicz R, van der Most R, Corbett KS, Suthar MS, Alter G, Roederer M, Sullivan NJ, Douek DC, Graham BS, Casimiro D, Seder RA. Vaccination with SARSCoV-2 Spike Protein and AS03 Adjuvant Induces Rapid Anamnestic Antibodies in the Lung and Protects Against Virus Challenge in Nonhuman Primates. bioRxiv. 2021; doi: 10.1101/2021.03.02.433390. PubMed PMID: 33688652; PMCID: PMC7941623.

11. Froberg J, Diavatopoulos DA. Mucosal immunity to severe acute respiratory syndrome coronavirus 2 infection. Curr Opin Infect Dis. 2021;34(3):181-6. doi: 10.1097/ QCO.0000000000000724. PubMed PMID: 33899752.

12. Martinez-Valdebenito C, Andaur C, Angulo J, Henriquez C, Ferres M, Le Corre N. Characterization of Oral Immunity in Cases and Close Household Contacts Exposed to Andes Orthohantavirus (ANDV). Front Cell Infect Microbiol. 2020;10:557273. doi: 10.3389/fcimb.2020.557273. PubMed PMID: 33224896; PMCID: PMC7670062.

13. Matsuda K, Migueles SA, Huang J, Bolkhovitinov L, Stuccio S, Griesman T, Pullano AA, Kang BH, Ishida E, Zimmerman M, Kashyap N, Martins KM, Stadlbauer D, Pederson J, Patamawenu A, Wright N, Shofner T, Evans S, Liang CJ, Candia J, Biancotto A, 
Fantoni G, Poole A, Smith J, Alexander J, Gurwith M, Krammer F, Connors M. A replication-competent adenovirus-vectored influenza vaccine induces durable systemic and mu-cosal immunity. J Clin Invest. 2021;131(5). doi: 10.1172/JCI140794. PubMed PMID: 33529172; PMCID: PMC7919717.

14. Salisch NC, Izquierdo Gil A, Czapska-Casey DN, Vorthoren L, Serroyen J, Tolboom J, Saeland E, Schuitemaker H, Zahn RC. Adenovectors encoding RSV-F protein induce durable and mucosal immunity in ma-caques after two intramuscular administrations. NPJ Vaccines. 2019;4:54. doi: 10.1038/s41541-019-0150-4. PubMed PMID: 31885877; PMCID: PMC6925274.

15. Patterson EI, Prince T, Anderson ER, Casas-Sanchez A, Smith SL, Cansado-Utrilla C, Solomon T, Grif-fiths MJ, Acosta-Serrano A, Turtle L, Hughes GL. Methods of Inactivation of SARS-CoV-2 for Downstream Bio-logical Assays. J Infect Dis. 2020;222(9):1462-7. doi: 10.1093/infdis/jiaa507. PubMed PMID: 32798217; PMCID: PMC7529010.

16. Henson BS, Wong DT. Collection, storage, and processing of saliva samples for downstream molecular applications. Methods Mol Biol. 2010;666:21-30. doi: 10.1007/978-160761-820-1 2. PubMed PMID: 20717775.

17. Brouwer PJM, Caniels TG, van der Straten K, Snitselaar JL, Aldon Y, Bangaru S, Torres JL, Okba NMA, Claireaux M, Kerster G, Bentlage AEH, van Haaren MM, Guerra D, Burger JA, Schermer EE, Verheul KD, van der Velde N, van der Kooi A, van Schooten J, van Breemen MJ, Bijl TPL, Sliepen K, Aartse A, Derking R, Bontjer I, Kootstra NA, Wiersinga WJ, Vidarsson G, Haagmans BL, Ward AB, de Bree GJ, Sanders RW, van Gils MJ. Potent neutralizing antibodies from COVID-19 patients define multiple targets of vulnerability. Science. 2020;369(6504):643-50. doi: 10.1126/science.abc5902. PubMed PMID: 32540902; PMCID: PMC7299281.

18. Premkumar L, Segovia-Chumbez B, Jadi R, Martinez DR, Raut R, Markmann A, Cornaby C, Bartelt L, Weiss S, Park Y, Edwards CE, Weimer E, Scherer EM, Rouphael N, Edupuganti S, Weiskopf D, Tse LV, Hou YJ, Margolis D, Sette A, Collins MH, Schmitz J, Baric RS, de Silva AM. The receptor binding domain of the viral spike protein is an immunodominant and highly specific target of antibodies in SARS-CoV-2 patients. Sci Im-munol. 2020;5(48). doi: 10.1126/sciimmunol.abc8413. PubMed PMID: 32527802; PMCID: PMC7292505.

19. Honjo K, Russell RM, Li R, Liu W, Stoltz R, Tabengwa EM, Hua Y, Prichard L, Kornbrust AN, Sterrett S, Marques MB, Lima JL, Lough CM, McCarty TP, Ketas TJ, Hatziioannou T, Bieniasz PD, Redden DT, Moore JP, Goepfert PA, Heath SL, Hahn BH, Davis RS. Convalescent plasma-mediated resolution of COVID-19 in a pa-tient with humoral immunodeficiency. Cell Rep Med. 2021;2(1):100164. doi: 10.1016/j. xcrm.2020.100164. PubMed PMID: 33521696; PMCID: PMC7817775.

20. MacMullan MA, Ibrayeva A, Trettner K, Deming L, Das S, Tran F, Moreno JR, Casian JG, Chellamuthu P, Kraft J, Kozak K, Turner FE, Slepnev VI, Le Page LM. ELISA detection of SARS-CoV-2 antibodies in saliva. Sci Rep. 2020;10(1):20818. doi: 10.1038/ s41598-020-77555-4. PubMed PMID: 33257702; PMCID: PMC7705674. 
21. Sterlin D, Mathian A, Miyara M, Mohr A, Anna F, Claer L, Quentric P, Fadlallah J, Devilliers H, Ghillani P, Gunn C, Hockett R, Mudumba S, Guihot A, Luyt CE, Mayaux J, Beurton A, Fourati S, Bruel T, Schwartz O, Lacorte JM, Yssel H, Parizot C, Dorgham K, Charneau P, Amoura Z, Gorochov G. IgA dominates the early neu-tralizing antibody response to SARS-CoV-2. Sci Transl Med. 2021;13(577). doi: 10.1126/scitranslmed.abd2223. PubMed PMID: 33288662; PMCID: PMC7857408.

22. Varadhachary A, Chatterjee D, Garza J, Garr RP, Foley C, Letkeman AF, Dean J, Haug D, Breeze J, Tray-lor R, Malek A, Nath R, Linbeck L. Salivary anti-SARS-CoV-2 IgA as an accessible biomarker of mucosal im-munity against COVID-19. medRxiv. 2020. doi: 10.1101/2020.08.07.20170258. PubMed PMID: 32817976; PMCID: PMC7430621.

23. Cervia C, Nilsson J, Zurbuchen Y, Valaperti A, Schreiner J, Wolfensberger A, Raeber ME, Adamo S, Weigang S, Emmenegger M, Hasler S, Bosshard PP, De Cecco E, Bachli E, Rudiger A, Stussi-Helbling M, Huber LC, Zinkernagel AS, Schaer DJ, Aguzzi A, Kochs G, Held U, Probst-Muller E, Rampini SK, Boyman O. Systemic and mucosal antibody responses specific to SARS-CoV-2 during mild versus severe COVID-19. J Allergy Clin Immunol. 2021;147(2):545-57 e9. doi: 10.1016/j.jaci.2020.10.040. PubMed PMID: 33221383; PMCID: PMC7677074.

24. Tosif S, Neeland MR, Sutton P, Licciardi PV, Sarkar S, Selva KJ, Do LAH, Donato C, Quan Toh Z, Higgins R, Van de Sandt C, Lemke MM, Lee CY, Shoffner SK, Flanagan KL, Arnold KB, Mordant FL, Mulholland K, Bines J, Dohle K, Pellicci DG, Curtis N, McNab S, Steer A, Saffery R, Subbarao K, Chung AW, Kedzierska K, Burgner DP, Crawford NW. Immune responses to SARS-CoV-2 in three children of parents with symptomatic COVID-19. Nat Commun. 2020;11(1):5703. doi: 10.1038/s41467-02019545-8. PubMed PMID: 33177504; PMCID: PMC7658256.

25. Brandtzaeg P. Secretory immunity with special reference to the oral cavity. J Oral Microbiol. 2013;5. doi: 10.3402/jom.v5i0.20401. PubMed PMID: 23487566; PMCID: PMC3595421.

26. Cerutti A, Chen K, Chorny A. Immunoglobulin responses at the mucosal interface. Annu Rev Immunol. 2011;29:273-93. doi: 10.1146/annurev-immunol-031210-101317. PubMed PMID: 21219173; PMCID: PMC3064559.

27. Gronblad EA. Concentration of immunoglobulins in human whole saliva: effect of physiological stimu-lation. Acta Odontol Scand. 1982;40(2):87-95. doi: 10.3109/00016358209041120. PubMed PMID: 6954831.

28. Zhou D, Chan JF, Zhou B, Zhou R, Li S, Shan S, Liu L, Zhang AJ, Chen SJ, Chan CC, Xu H, Poon VK, Yuan S, Li C, Chik KK, Chan CC, Cao J, Chan CY, Kwan KY, Du Z, Lau TT, Zhang Q, Zhou J, To KK, Zhang L, Ho DD, Yuen KY, Chen Z. Robust SARSCoV-2 infection in nasal turbinates after treatment with systemic neutralizing antibod-ies. Cell Host Microbe. 2021;29(4):551-63 e5. doi: 10.1016/j.chom.2021.02.019. PubMed PMID: 33657424; PMCID: PMC7904446.

29. Chodick G, Tene L, Patalon T, Gazit S, Tov AB, Cohen D, Muhsen K. The effectiveness of the first dose of BNT162b2 vaccine in reducing SARS-CoV-2 infection 13-24 days after immunization: real-world evidence. medRxiv. 2021; doi: 
10.1101/2021.01.27.21250612.

30. Levine-Tiefenbrun M, Yelin I, Katz R, Herzel E, Golan Z, Schreiber L, Wolf T, Nadler V, Ben-Tov A, Kuint J, Gazit S, Patalon T, Chodick G, Kishony R. Decreased SARS-CoV-2 viral load following vaccination. medRxiv preprint. 2021; doi: $\underline{10.1101 / 2021.02 .06 .21251283 .}$.

31. Piccoli L, Park YJ, Tortorici MA, Czudnochowski N, Walls AC, Beltramello M, Silacci-Fregni C, Pinto D, Rosen LE, Bowen JE, Acton OJ, Jaconi S, Guarino B, Minola A, Zatta F, Sprugasci N, Bassi J, Peter A, De Marco A, Nix JC, Mele F, Jovic S, Rodriguez BF, Gupta SV, Jin F, Piumatti G, Lo Presti G, Pellanda AF, Biggiogero M, Tarkowski M, Pizzuto MS, Cameroni E, Havenar-Daughton C, Smithey M, Hong D, Lepori V, Albanese E, Ceschi A, Bernasconi E, Elzi L, Ferrari P, Garzoni C, Riva A, Snell G, Sallusto F, Fink K, Virgin HW, Lanzavecchia A, Cor-ti D, Veesler D. Mapping Neutralizing and Immunodominant Sites on the SARS-CoV-2 Spike Receptor-Binding Domain by Structure-Guided High-Resolution Serology. Cell. 2020;183(4):1024-42 e21. doi: 10.1016/j.cell.2020.09.037. PubMed PMID: 32991844; PMCID: PMC7494283.

32. Finkelstein MT, Mermelstein AG, Parker Miller E, Seth PC, Stancofski ED, Fera D. Structural Analysis of Neutralizing Epitopes of the SARS-CoV-2 Spike to Guide Therapy and Vaccine Design Strategies. Viruses. 2021;13(1). doi: 10.3390/v13010134. PubMed PMID: 33477902; PMCID: PMC7833398.

33. Seaton KE, Deal A, Han X, Li SS, Clayton A, Heptinstall J, Duerr A, Allen MA, Shen X, Sawant S, Yates NL, Spearman P, Churchyard G, Goepfert PA, Maenza J, Gray G, Pantaleo G, Polakowski L, Robinson HL, Grant S, Randhawa AK, Huang Y, Morgan C, Grunenberg N, Karuna S, Gilbert PB, McElrath MJ, Huang Y, Tomaras GD, Niaid Hiv Vaccine Trials Network ST. Meta-analysis of HIV-1 vaccine elicited mucosal antibodies in hu-mans. NPJ Vaccines. 2021;6(1):56. doi: 10.1038/s41541-021-00305-8. PubMed PMID: 33859204; PMCID: PMC8050318.

\section{FOOTNOTES}

Submitted April 9,2021 | Accepted May 13, 2021 | Published June 7, 2021

\section{COPYRIGHT}

Copyright (C) 2021 Pathogens and Immunity. This is an open-access article distributed under the terms of the Creative Commons Attribution 4.0 International License. 